\title{
The Death Penalty for State Officers Who Corrupted Social Aid for the Poor during COVID-19
}

\author{
Junaedi $^{1 *}$

\section{*Corresponding Author} \\ Junaedi \\ Article History \\ Received: 29.10 .2021 \\ Accepted: 01.12.2021 \\ Published: 24.01.2022
}

${ }^{1}$ Government Study, Universitas Muhammadiyah Makassar, Sultan Alauddin Street, No. 259, Makassar

\begin{abstract}
Death Penalty For State Officials Who Corrupt Social Assistance for Small People During the Covid-19 Period Has the death penalty been enacted for State Officials Corruption of Social Assistance for Small People during the Covid-19 Period in Indonesia at this time. Laws governing the death penalty for state officials who commit corruption Social assistance for the underprivileged during the Covid-19 period in Indonesia. The purpose of this study is to find out and analyze analytically and comprehensively about the implementation of the death penalty for state officials who commit corruption. Indonesia is a legal state that has many legal institutions that overshadow the problems that occur in Indonesia. Indonesia has many problems that are increasing over time, especially the rampant corruption cases that occur in Indonesia and have experienced a drastic increase. Lately, the problem of corruption in the Social Assistance Covid-19 is being hotly discussed by the public, especially in the mass media, both local and national, and even internationally. The Covid-19 Bansos corruption case that is rife in Indonesia today is not only a case of corruption caused by state officials and high-ranking officials, but even high-class businessmen have started to enliven the case. Even the Minister has shown his role in the case, such as the corruption case that ensnared Juliardi Batubara, Minister of Social Affairs of the Republic of Indonesia. Corruption seems to have become a common thing for Indonesia, but it is very detrimental to the Indonesian nation itself. Corruption causes a lot of losses both for the state and for the people. The conclusion that the chairman of the Corruption Eradication Commission (KPK) In last July, Firli had conveyed about the demand for the death penalty for perpetrators of budget corruption in handling the Covid-19 pandemic. He claims to have warned that corruption during a disaster or pandemic can be punishable by the death penalty. The threat of the death penalty for perpetrators of corruption is regulated in Article 2 paragraph (2) of Law no. 31 of 1999 concerning the Eradication of Criminal Acts of Corruption. The regulation of the article reads: In the event that the criminal act of corruption as referred to in paragraph (1) is carried out under certain circumstances, the death penalty may be imposed.
\end{abstract}

Keywords: Death penalty for officials, corruption of the Covid-19 Social Assistance, Poor People.

\section{INTRODUCTION}

Our country is currently seriously ill faced with the COVID-19 virus disaster and has also become an international problem. Until now, Indonesia has not implemented a policy for lockdown with the aim of breaking the chain of the virus. This phenomenon really gives a big blow, especially from the social aspect of today's society with the implementation of everything done at home (stay at home and work from home). Communities with the application of everything in their homes also indirectly have an impact on the economy. The current state must be present as a counterweight to their social life in their economic emphasis in order to be overcome. Currently, the government has launched social assistance from both the central and local governments. The process must have effective supervision by law enforcement authorities. Our country is a country that implements very strict regulations on corruption, especially in the use of social funds intended for assistance in a state of emergency (Junaedi, 2021). Politicization tactics and ticks, which are packaged with Covid-19 assistance packages via Large-Scale Social Restrictions (PSBB) are unlawful act.

Indonesia is a legal state that has many legal institutions that overshadow the problems that occur in Indonesia. Indonesia has many problems that are increasing over time, especially the rampant corruption cases that occur in Indonesia and have experienced a drastic increase.

Copyright (C) 2022 The Author(s): This is an open-access article distributed under the terms of the Creative Commons Attribution 4.0 International License (CC BY-NC 4.0) which permits unrestricted use, distribution, and reproduction in any medium for noncommercial use provided the original author and source are credited. 
Lately, the problem of corruption in the Social Assistance Covid-19 is being hotly discussed by the public, especially in the mass media, both local and national, and even internationally. The Covid-19 Bansos corruption case that is rife in Indonesia today is not only a case of corruption caused by state officials and high-ranking officials, but even high-class businessmen have started to enliven the case. Even the Minister has shown his role in the case, such as the corruption case that ensnared Juliardi Batubara, Minister of Social Affairs of the Republic of Indonesia. Corruption seems to have become a common thing for Indonesia, but it is very detrimental to the Indonesian nation itself. Corruption causes a lot of losses both for the state and for the people.

The Covid-19 social assistance corruption has become a product of the attitude of a group of people who use money as a standard of truth and as absolute power. As a result, the wealthy corrupt and corrupt politicians who have excess money can enter the ruling elite and are highly respected. They will also occupy a high social status in the eyes of society.

The Covid-19 social assistance corruption began with the increasing urgency of the desired development efforts, while the bureaucratic process was relatively slow, so that every person or agency wanted a quick shortcut by providing rewards by providing facilitation payments (bribes). This practice will continue as long as there is no control from the government and society, resulting in a group of employees termed OKB-OKB (new rich people) who enriches them.

This study is also expected to contribute to the development of the theory of legislation governing the death penalty for state officials who commit corruption. Social assistance for the underprivileged during the Covid-19 period in Indonesia. The results of this study can be a reference or further research for researchers in the field of government science who want to study further about the provisions in the legislation governing the death penalty for state officials who commit corruption.

TEMPO.CO, Jakarta - The Corruption Eradication Commission (KPK) continues to explore companies that have received a share in the provision of social assistance or Covid-19 social assistance from former Social Minister Juliari Batubara.

The KPK summoned a number of company representatives, including PT Indonesia Trading Company, PT Riskaindo, PT Darma Lanrara Jaya, PT Asricitra Pratama and PT Afira Indah Megatama.

Acting KPK spokesman Ali Fikri said the company was a vendor providing Covid-10 social assistance packages. Examining for the suspect, a former official commitment maker at the Ministry of Social Affairs, Matheus Joko Santoso, investigators are investigating the alleged flow of money to the Minister of Social Affairs Juliari Peter Batubara from the witnesses. "The KPK investigation team is still investigating," said Ali, Thursday, March 18, 2021.

The four company representatives who were summoned were actually only a few of them who allegedly received a quota for the provision of social assistance. This direct appointment project is worth Rp 6.46 trillion, with a total of 23.7 million packages of basic goods. Held from April to December 2020, the distribution of social assistance was carried out in 12 states with more than 200 company names appointed.

The direct appointment of the company is not without reason. From the outset, the Covid-19 social assistance packages were allegedly owned by a number of officials. Companies that want to get the package are suspected of having affiliates or getting recommendations.

The source, who is familiar with the investigation into the Covid-19 social assistance corruption case, said that Matheus disclosed the names of vendors, as well as officials suspected of being affiliated with the company. A number of officials, ranging from the Minister of Social Affairs to politicians, are allegedly mentioned in the data.

The purpose of this study is to find out the factors that apply the death penalty for state officials who commit corruption, social assistance for the underprivileged people in the current Covid-19 era in Indonesia and to find out about the provisions in the legislation governing the death penalty for state officials who Corruption Social Assistance for Small People During the Covid-19 Period in Indonesia.

\section{METHODS}

The research approach of this article uses a legal analytical descriptive method, which starts from an effort to explain the existing problems through data-based analysis. The data was obtained by taking into account the problems that could arise in the provisions of the legislation governing the Death Penalty for State Officials Who Do Corrupt Social Assistance for Small People During the Covid-19 Period in Indonesia. The data collected comes from secondary data from the results of research that has been done previously, plus the latest data that has been widely spread in various 
other supporting literature. Furthermore, the solution to these problems is analyzed as an effort made by the local government, so that it can inspire other local governments to make improvements in services to the community.

\section{RESULTS AND DISCUSSION}

According to Fockema Andrea, the word corruption comes from the Latin corruptio or corruptus:

\section{Mubyarto quotes Smith's opinion as follows}

"On the whole corruption in Indonesia appears to present more of a recurring political problem than an economic one. It undermines the legitimacy of the government in the eye of the young, educated elite and most civil servants.... Corruption reduces support for the government among elites at the province and regency level. politics rather than economy. It touches on the legitimacy (legitimacy) of government in the eyes of the younger generation, educated elites and civil servants in general. Corruption reduces support for government from elite groups at the provincial and district levels) (Mubyant)".

\section{More firmly what was stated by Gunnar Myrdal as follows?}

The problem is of vital concern to the government of South Asia, because the habitual practice of bribery and dishonesty pavers the way for an authoritarian regime which justifies it self by the disclosures of corruption has regularly been advance as a main justification for military take overs" (The issue (corruption; author) is an important one for governments in South Asia because habits of bribery and dishonesty pave the way for exposing corruption and punishing violators. Combating corruption is usually the main justification for military coups (Myrdal, 1977) Opinions of some experts regarding the definition of criminal acts of corruption, corruption is usually used as the main justification for military coups).

There are various opinions, including the opinion that corruption is a deviation from formal duties in official government positions, not only in executive positions but also in the legislature, political parties, audif, BUMN/BUMD to private sector officials. Another opinion focuses on acts of corruption on the basis of whether a person's actions are contrary to the interests of the community, using a measure of whether the action is considered corrupt by public officials or not.

The definition of corruption in the General Indonesian Dictionary (W.J.S Poerwadarminta), is defined as a fraudulent act, can be bribed and immoral. Meanwhile, according to the Big Indonesian Dictionary, corruption is the misappropriation or embezzlement of state or company money and so on for personal or other people's interests.

\section{Definition of corruption based on the Black Law Dictionary}

"Corruption an act done with an intent to give some advantage inconsistent with official duty and and the rights of others. The act of an official or fiduciary person who unlawfully and wrongfully uses his station or character to procure some benefit for himself or for another person, Contrary to duty and the rights of others. contrary to official duties and other truths.

An act of something official or someone's belief which violates the law and is full of mistakes using a number of advantages for himself or others that are contrary to duties and other truths) (Surachmin, 2011) ".

\section{Social Assistance}

Social assistance is a form of transfer (can be in the form of money/goods) intended for groups/community members/political parties to improve their welfare through productive distribution criteria. In order for social assistance to be carried out in an accountable, transparent, and fair manner, it is necessary to establish an independent verification team that will selectively assess both the criteria for recipients and the social assistance proposal itself.

After the arrest of the Minister of Social Affairs, Juliari Batubara by the Corruption Eradication Commission (KPK) in the alleged corruption case of social assistance funds for residents affected by Covid-19, President Joko Widodo's appeal, which long before had reminded his cabinet not to play around in the use of disaster budgets, especially funds for the COVID-19 pandemic-19 (bbc.com, 2020).

In fact, the corruption of social assistance funds for residents affected by Covid-19 has jolted public awareness after Tempo Magazine investigated this fantasy-worthy rasuah case. This is because the government has allocated a large (special) budget to prevent and deal with the COVID-19 pandemic for affected residents. The funds come from the relocation of ministries and agencies (K/L) budgets whose priority use can still be deferred. The disbursement of social assistance funds of Rp 62 trillion shows the government's seriousness in preventing and handling the Covid-19 outbreak. The concerns of many parties regarding the potential corruption of social assistance funds are not without reason. The $\mathrm{KPK}$, for example, has received 118 public complaints regarding the distribution of social assistance funds through the 
JAGA application since it was first launched by the KPK on June 5, 2020. Public reports received by the KPK came from 78 local governments, consisting of from 7 provinces and 71 districts/cities (Sari, 2020).

Not only the KPK, the Indonesian Ombudsman also received hundreds of reports from various elements of society regarding the misuse of social assistance funds, which can be classified into five problem points: (1) uneven distribution of aid in terms of time and people in the target area; (2) people who are more urgently hungry but are not registered, or vice versa; (3) people who are registered but do not receive assistance; (4) unable to receive assistance, because they have an immigrant ID card; and (5) the lack of socialization of the means of complaints to recipients of assistance (Harahap, 2020).

The Indonesian Forum for Budget Transparency (FITRA) also identified potential problems with the misuse of social assistance funds at five vulnerable points: (1) data collection carried out by officers in a haphazard manner; (2) recipients of assistance are mistargeted; (3) embezzlement of aid funds; (4) the amount of assistance does not match the amount received; (5) illegal levies carried out by unscrupulous aid distributors; (6) double financing of the aid budget (APBN/APBD/APBDesa) (Hasan, 2020).

We all know that currently there is an additional expenditure from the central government in the 2020 State Budget of Rp.405.1 Trillion, of Rp.110 Trillion or 27\%, of the people's money (APBN) will be allocated for social safety nets, including allocation for assistance to communities affected by Covid-19. Likewise, from the results of the refocusing of activities and the reallocation of local government budgets as of April 16, 2020, the total budget that was reallocated was Rp. 56.57 trillion or $5.13 \%$ of the total 2020 APBD, which was Rp. 1,102 trillion. from Rp. 56.57 trillion of which Rp.17.5 trillion or around 31\% was allocated for grant/social assistance expenditures in an effort to overcome the impact of the Covid-19 pandemic in the regions including Indramayu Regency, West Java Province.

"Frills" for candidates for regional head and/or deputy regional head, both incumbent and non-incumbent, because if assistance is from the regional government, it is sufficient to provide a regional government logo/symbol without a photo and/or name of the regional head and/or deputy regional head. which is distributed through the head of service, inspectorate, sub-district head, village head (kuwu/lurah), RW/RT and other agencies under the command of regional heads who wish to nominate themselves as regional heads in the second period (incumbent), based on Article 71 paragraph (3) for example, there are at least 4 (four) elements. First, the subject is the Regional Head or Deputy Regional Head. Second, there is a government program or activity, and third, it is carried out 6 (six) months before the determination of the candidate. The three elements are fulfilled, but because there is no candidate pair, it is not complete.

\section{Surveillance System}

Is the supervision of the misuse of the Covid-19 social assistance via PSBB that must be carried out especially by Bawaslu, KPK and other agencies in maximizing supervision, Provincial/Regency/City Bawaslu as electoral oversight institutions also expect support and commitment from other supervisory institutions in the regions, of course and we understand together that the administration of regional government, the executive does not work alone. There is a DPRD as a strategic partner for the Regional Government of Indramayu Regency and others within the territory of the Republic of Indonesia which also has a supervisory function over the work of the regional government. There is an Inspectorate, as its internal supervisor, but strangely they support the policies carried out by the incumbent, especially if they are in the same line (coalition), they will be silent a thousand languages even though it is against the law.

\section{KPK Authority}

As for Ministers, State Officials (DPR RI/DPRD) regional heads/PIT who violate the criminal law because of their actions, the KPK/Prosecutors/Police can ensnare them based on Law no. 31 of 1999 as amended by Law no. 20 of 2001 concerning the Eradication of Criminal Acts of Corruption, Likewise if the assistance comes from prospective candidates who are not incumbents. No need to give a name, self-image/photo, or even vision and mission as a "casing". Because more or less there will be imaging content (not sincerity) and socialization in order to face electoral contestation.

The potential for corruption in social assistance funds, on the one hand, is certainly a concern for the central government (especially the president, the KPK and the National Police) to those who have been mandated to distribute social assistance funds in a prudent, transparent, accountable, effective, and targeted manner. On the other hand, the 'threats' of the government and law enforcement on individuals who have the potential to corrupt social assistance funds will certainly be a means of support for the government in gaining public sympathy. As a political reality and legal fact, the potential for corruption in social assistance funds certainly attracts the attention of various media to be reported on. This is because the discourse on corruption is related to the news value aspect in terms of the content, the actor (person) and the position held by the actors (prominence; eminence), in addition to the material-event aspect or the extraordinary nature of the case, as well as the state financial loss it causes. 


\section{Why social assistance is prone to politicization and must be monitored}

In the legal context, corruption is a product of weak law enforcement and public oversight of the practice of state power. These two weaknesses arise due to poor government transparency and accountability (Alkotsar, 2009). Misuse of distribution (such as corruption of social assistance funds) to the people can also be categorized as a form of political corruption, namely a form of abuse of mandates, mandates, and authorities entrusted by the people. In the context of the theory of justice, political corruption will have a systemic impact, namely the disruption of the function of equity and justice for the people - both distributive justice (based on the principle of proportionality) and commutative justice (based on the principle of equality; without difference) (Rawls, 1999; Hasanuddin, 2018).

Political corruption can be motivated by various motives, such as: (1) abuse of authority by administrators of state power; (2) the action was shown from the beginning by using political or economic influence; (3) money from the proceeds of crime is invested for political activities/activities; (4) the existence of an intention (motive) which is manifested in the form of certain actions or actions that can be qualified as a political interest; (5) interpretation of the meaning of politics, political activities, and interests interpreted in various legal considerations (Alkotsar, 2009); and in many cases (political corruption) there is always a corporate role that is used as a means or object of crime, which is in alliance with political authority holders in an organized, solid, and integrated manner (Widjojanto, 2017).

The President of the Republic of Indonesia, Joko Widodo, ensured that the government would disburse a stimulus worth Rp405 trillion. The funds are used to deal with the Covid-19 attack, maintain people's purchasing power, and restrain the economic rate so that it does not stagnate. Of that amount, Rp. 110 trillion was disbursed for social safety nets which are clearly for the benefit of the people in need, not for the sake of selling politics by unscrupulous regional heads.

There are several reasons why social assistance is prone to being misappropriated both for political purposes and for the purpose of other violations; (1) Mentality and behavior of regional heads who are deviant, corrupt, and have no integrity. This factor is the biggest contributor to the misuse of social assistance funds; (2) That mentality is coupled with a typology of using social assistance that is easier and more flexible. This means that the planning, disbursement and accountability of funds is easy compared to the use of other government programs; (3) The non-functioning of the supervisory institution thus opens the door to irregularities. "If the DPRD and the inspectorate supervise the maximum, the politicization of social assistance will not occur; (4) Regional heads do not excel so they are afraid of not being reelected in the upcoming elections, because they, especially the incumbents, are not confident in relying on the performance that has been done, That's why I try to beautify myself in an instant way and use state resources too through the Covid-19 social assistance which is packaged in a PSBB package.

The mode of abuse of the Covid-19 social assistance via PSBB can be seen in the image below:

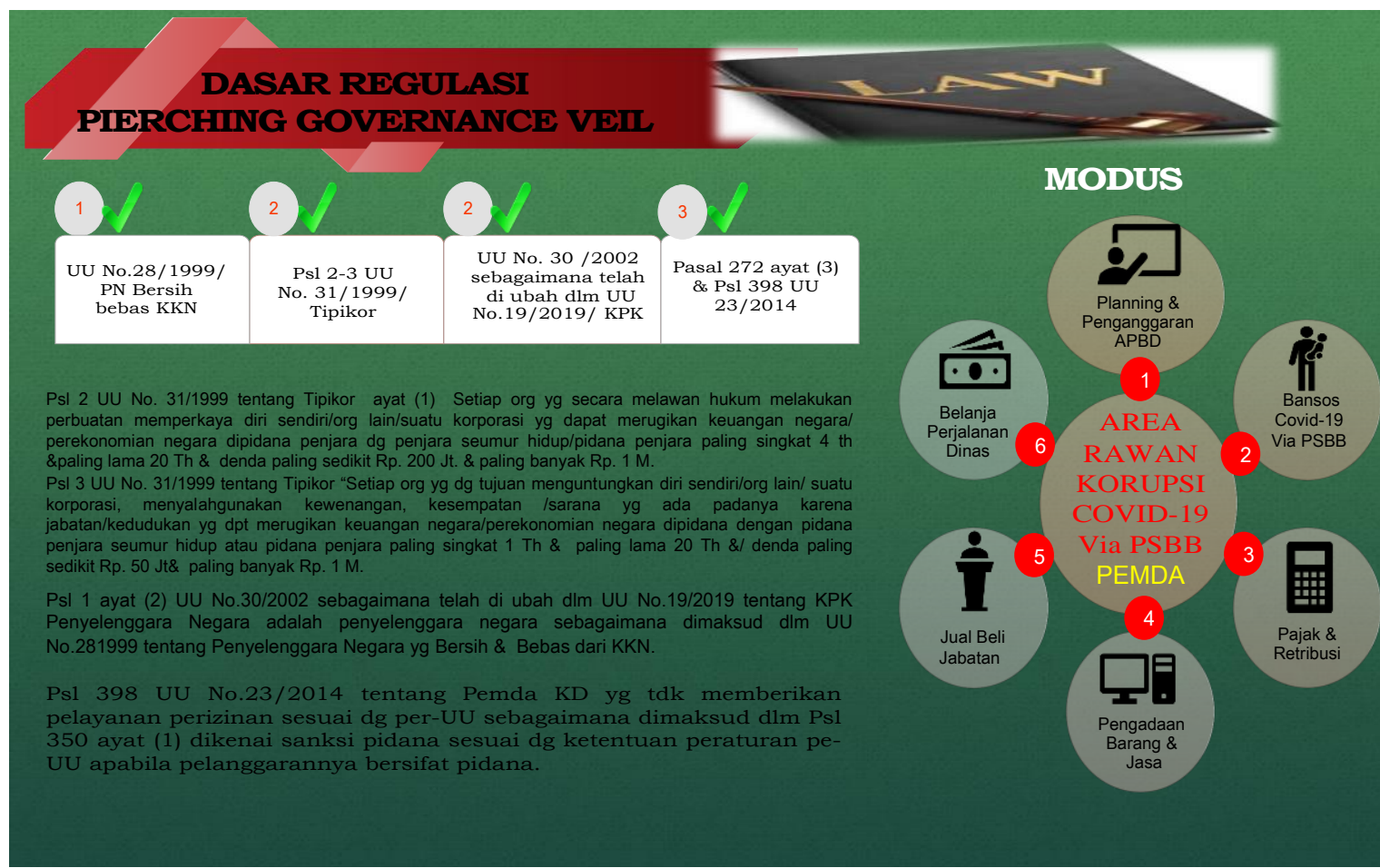

Fig-1: Mode of Abuse of COVID-19 Social Assistance 
Then what are the legal links and threats to perpetrators who carry out Covid-19 manipulation actions that are packaged with Covid-19 social assistance via Large-Scale Social Restrictions (PSBB) or whatever their names are carried out by regional heads (Governor/Regent/Mayor/Village Head? ) and other agencies so that several legal sanctions may be imposed, including the following:

\section{Crime Based on the Corruption Law and the Criminal Code and the KPK}

The criminal threat for social assistance mafias related to Covid-19 packaged with PSBB or others (Governor/Regent/Mayor/Village Head and ASN) who deviate from Covid social assistance packaged by PSBB can be subject to Law No. 31 of 1999 as amended by Law no. 20 of 2001 concerning the Eradication of Corruption Crimes Articles 2 and 3 are punishable by a maximum of 20 years in prison and a maximum fine of Rp. 1 billion," "Subsidiary to Article 372 of the Criminal Code, with a threat of 4 years.

In Article 2 paragraph (2) of Law no. 31 of 2001 concerning the Eradication of Corruption Crimes. It is clearly stated in the Law in the explanation section, "that a person suspected of committing a criminal act of corruption under certain circumstances will be given the death penalty". The definition of what is meant by "certain circumstances" in this provision is intended as "a burdensome for perpetrators of criminal acts of corruption if the crime is committed at a time when the country is in a state of danger in accordance with applicable laws, at the time of a national natural disaster, as a countermeasures against acts of corruption. corruption, or when the country is in a state of economic and monetary crisis". The COVID-19 event that occurred has been determined by the President through Presidential Decree No. Year 2020 concerning the Determination of Non-Natural Disasters for the Spread of Corona Virus Disease 2019 (COVID-19) as National Disasters.

This has been strengthened by the Corruption Eradication Commission (KPK) by issuing Circular No. 11 of 2020, April 21, 2020 regarding the Use of Integrated Social Welfare Data (DTKS) and non-DTKS data in the provision of Social Assistance (Bansos) to the community in an effort to overcome the impact of the corona virus pandemic (Covid-19).

DTKS managed by the Ministry of Social Affairs is a database that has been used to provide social assistance to the community nationally. DTKS is constantly improving. Through the SE addressed to the Chair of the Task Force for the Acceleration of Handling Covid-19 at the national and regional levels, and the heads of the ministries/institutions/regional governments, the KPK recommended five things so that data collection and distribution of social assistance was right on target.

Ministries/agencies and local governments can collect data in the field, but still refer to DTKS. If a discrepancy is found, assistance can still be provided and the data for the new beneficiaries must be reported to the Social Service or the Social Welfare Data and Information Center (Pusdatin) of the Ministry of Social Affairs to be proposed for inclusion in the DTKS according to applicable regulations.

Vice versa, if the beneficiary is registered with the DTKS but the facts on the ground do not meet the requirements as a beneficiary, then it must be reported to the Social Service/Pusdatin for DTKS improvement,".

To ensure that the data is valid, the data on social assistance recipients from other programs or data collected in the field must be matched with the NIK data with the local Dukcapil Office data.

Ministries/agencies and local governments ensure open access to data on aid recipients, aid realization, and available budgets to the public as a form of transparency and accountability.

The KPK encourages involvement and increased community participation in supervising. For this reason, ministries/agencies and local governments need to provide facilities for public complaints services that are easy, inexpensive and can be followed up immediately.

Based on the provisions stipulated in Article 6 letter (a), (b), and (c) of Law no. 19 of 2019 concerning the Second Amendment to Law no. 30 of 2002 concerning the Corruption Eradication Commission, the KPK is tasked with, among other things, to take preventive, coordinating, and monitoring actions so that corruption does not occur. at the Directorate General of Population and Civil Registration of the Ministry of Home Affairs (Ditjen Dukcapil Kemendagri) based on the Population Identification Number (NIK), so that the recipient of assistance at DTKS is believed to be based on the NIK. 
Another reason for using DTKS is that improvements to the accuracy of the status of beneficiaries are carried out periodically with the help of data collection by local governments and validation verification procedures (verivali), so that it is believed that the recipients have been on target.

Regarding the corruption of the Covid-19 Social Assistance (Bansos) carried out by the Minister of Social Affairs, Juliari P. Batubara, the KPK has been named a suspect in the alleged corruption case in the procurement of social assistance (bansos) for handling Covid-19. Juliari's suspect status also ensnared Ministry of Social officials and a number of parties who gave bribes.

This case began with the procurement of social assistance for handling Covid-19 in the form of basic food packages at the Ministry of Social Affairs of the Republic of Indonesia in 2020 with a value of around Rp. 5.9 trillion. The total contracts are 272 contracts and implemented in two periods.

Juliari then appointed Matheus Joko Santoso (MJS) and Adi Wahyono (AW) as Commitment Making Officers (PPK) in implementing the project by direct appointment of partners.

For the fee for each social assistance package, it was agreed that it was Rp. 10,000 per food package from a value of Rp. 300 thousand per social assistance package that Juliari would receive.

From May to November, Matheus and Adi then made work contracts with several suppliers as partners, including Ardian I. M. (AIM), Harry Sidabuke (HS) and also PT Rajawali Parama Indonesia (RPI) which allegedly belonged to Matheus.

"The appointment of PT RPI as one of the partners was allegedly known to JPB (Juliari Peter Batubara) and approved by AW (Adi Wahyono)," (KPK Chairman Firli Bahuri at a press conference December 6, 2020).

During the first period of the basic food assistance package, it was alleged that a fee of Rp 12 billion was received, the distribution of which was given in cash by Matheus to Juliari through Adi with a value of around Rp. 8.2 billion. The money distribution is then managed by EK (Eko) and SN (Shelvy N) who are Juliari's confidants and secretary at the Ministry of Social Affairs to be used to pay for Juliari's various personal needs. SN was also named a suspect in this case.

Meanwhile, for the second period of the implementation of the basic food assistance package, collected fees from October-December 2020 amounted to around Rp. 8.8 billion, which is also expected to be used for Juliari's needs. Apart from Juliari, four other people are suspects, namely Matheus, Adi, as the recipient and Ardian and Hari as the giver.

Juliari is suspected of violating Article 12 letter a or Article 12 letter (b) or Article 11 of Law (UU) Number 31 of 1999 as amended by Law Number 20 of 2001 concerning Eradication of Criminal Acts of Corruption in conjunction with Article 55 paragraph (1) to ( 1) Criminal Code.

\section{Threat of Death Penalty}

Corruption has become a serious disease in this country and is very difficult to cure (Pertiwi \& Ainsworth, 2021). Various efforts to prevent and eliminate corrupt practices have been carried out very often. Both with the formation of laws and regulations as well as the establishment of a commission or agency for the prevention of corruption. But corruption never wants to leave the Indonesian people. There is corruption in the executive branch, as well as in the legislature and judiciary. Not to mention in several state-owned enterprises and non-ministerial state institutions. The phenomenon of corruption has made people hot and angry. Because the perpetrators of corruption have taken people's rights by force. However, law enforcement against the perpetrators is not going well. Most of the criminals are punished lightly. However, the law provides for the death penalty for the perpetrators. The community hopes that the perpetrators of corruption are punished to the fullest extent, so that justice and public welfare can be fulfilled (Fijnaut $\&$ Huberts, 2000). In the case of corruption, the perpetrators can be sentenced to the maximum amount of punishment because the perpetrators must be held accountable for their actions. In every act that contains an element of error or crime, then the crime or error is what causes a person to be punished. In this case, the principle of no crime without guilt is known (Geen Straf zonder Schuld or no punishment without guilt) which is the main principle in the responsibility of the maker for the crime committed. This unwritten law principle is embraced by Indonesian criminal law today. The principle of no crime without fault is violated by strict liability and vicarious liability (Widowaty, 2012).

Chairman of the Corruption Eradication Commission (KPK) In last July, Firli had conveyed about the demand for the death penalty for perpetrators of corruption in the budget for handling the Covid-19 pandemic. He claims to have 
warned that corruption during a disaster or pandemic can be punishable by the death penalty. "This is not a joke. I really ask that later if someone is caught, I ask that they be threatened with the death penalty. Even the death penalty is executed," Firli told CNN Indonesia.com, at the Transmedia Building, Jakarta on July 29, 2020.

The threat of the death penalty for perpetrators of corruption is regulated in Article 2 paragraph (2) of Law No. 31 of 1999 concerning the Eradication of Criminal Acts of Corruption. The regulation of the article reads: In the event that the criminal act of corruption as referred to in paragraph (1) is carried out under certain circumstances, the death penalty may be imposed.

\section{Anti-Corruption Behavior Index}

The Anti-Corruption Behavior Index (IPAK) for 2020 can be seen in the image below:

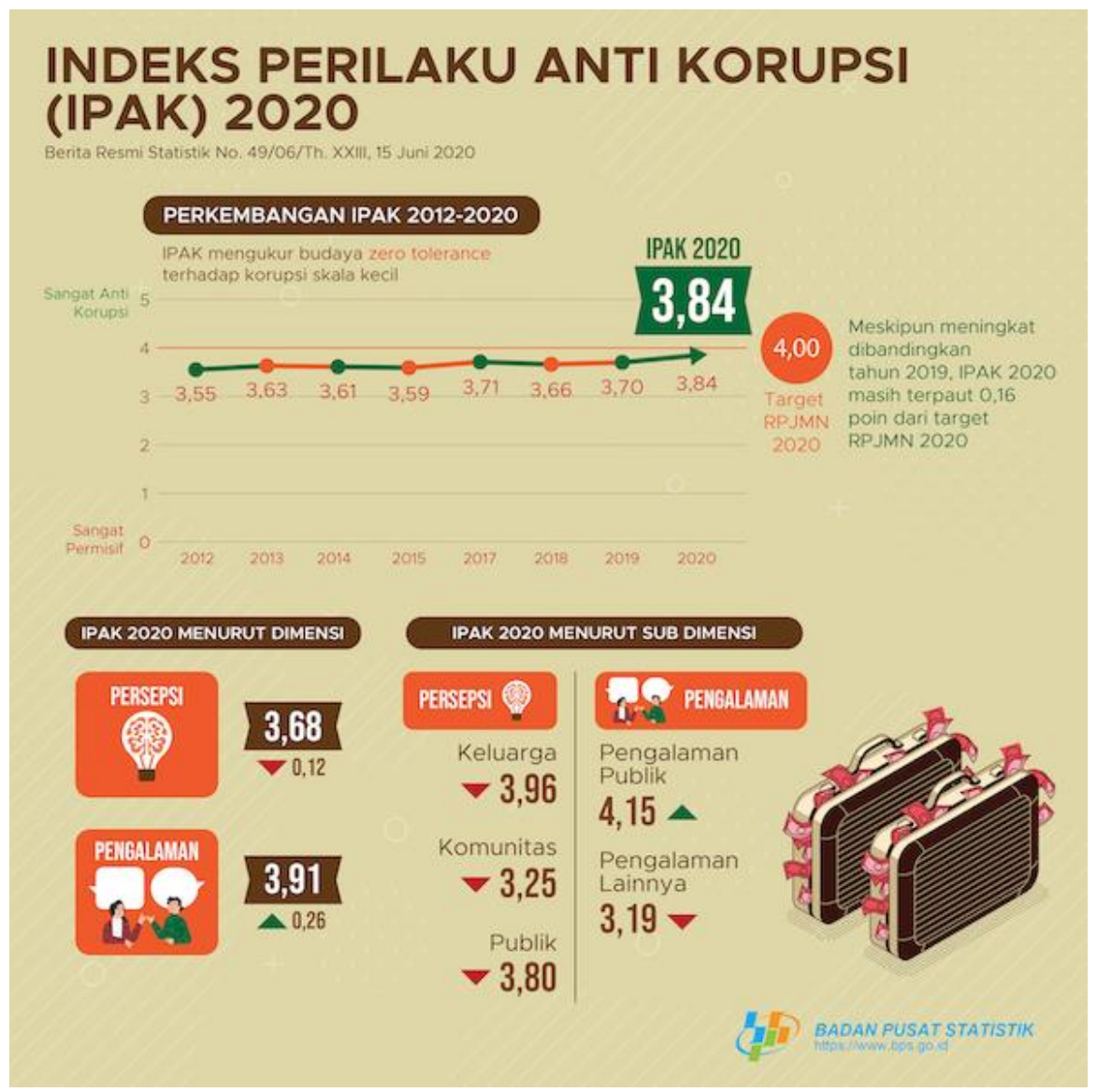

\section{Poverty Profile in Indonesia}

The percentage of poor people in March 2020 rose to 9.78 percent. The percentage of poor people in March 2020 was 9.78 percent, an increase of 0.56 percentage points against September 2019 and an increase of 0.37 percentage points against March 2019. The number of poor people in March 2020 was 26.42 million people, an increase of 1.63 million people in September 2019 and an increase of 1.28 million people in March 2019. The percentage of poor people in urban areas in September 2019 was 6.56 percent, rising to 7.38 percent in March 2020. While the percentage of poor people in rural areas in September 2019 by 12.60 percent, rising to 12.82 percent in March 2020.

Compared to September 2019, the number of poor people in March 2020 in urban areas increased by 1.3 million people (from 9.86 million people in September 2019 to 11.16 million people in March 2020). Meanwhile, rural areas increased by 333.9 thousand people (from 14.93 million people in September 2019 to 15.26 million people in March 2020). The Poverty Line in March 2020 was recorded at Rp454,652/capita/month with the composition of the Food Poverty Line of Rp335,793,- (73.86 percent) and the Non-Food Poverty Line of Rp118,859 (26.14 percent) . In March 2020 , on average, poor households in Indonesia had 4.66 household members. Thus, the size of the Poverty Line per poor household on average is IDR 2,118,678,-/poor household/month.

\section{Poverty Profile in Indonesia}

The poverty profile in Indonesia in March 2020 can be seen in the image below: 


\section{PROFIL KEMISKINAN DI INDONESIA MARET 2020 \\ Berita Resmi Statistik No. 56/O7/Th. XXIII, 15 Juli 2020}

\section{Jumlah (Juta Orang) dan Persentase Penduduk Miskin}

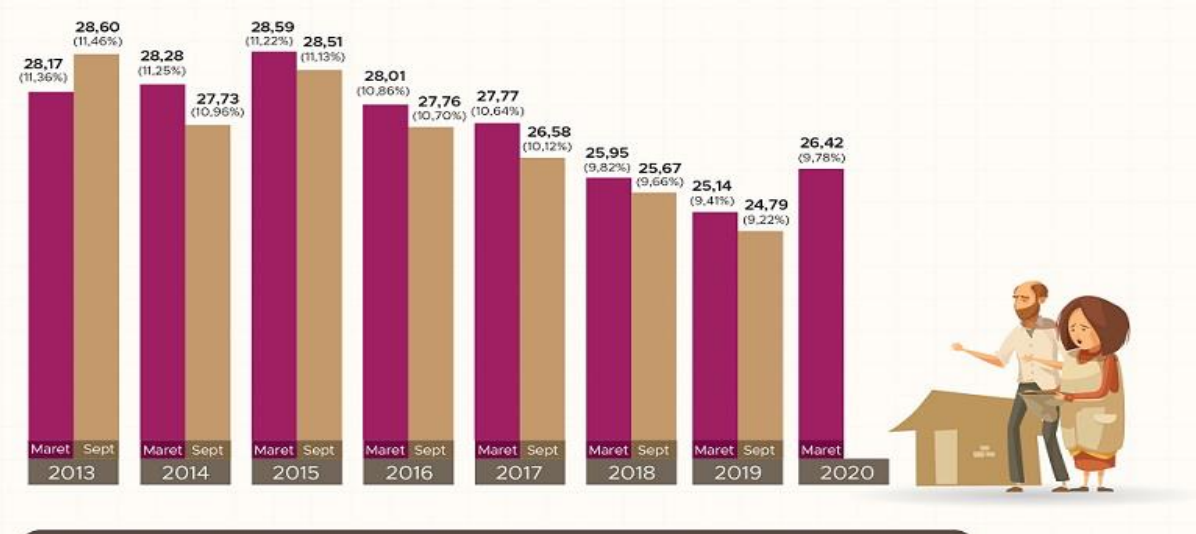

Jumlah (Juta Orang) dan Persentase Penduduk Miskin Menurut Pulau

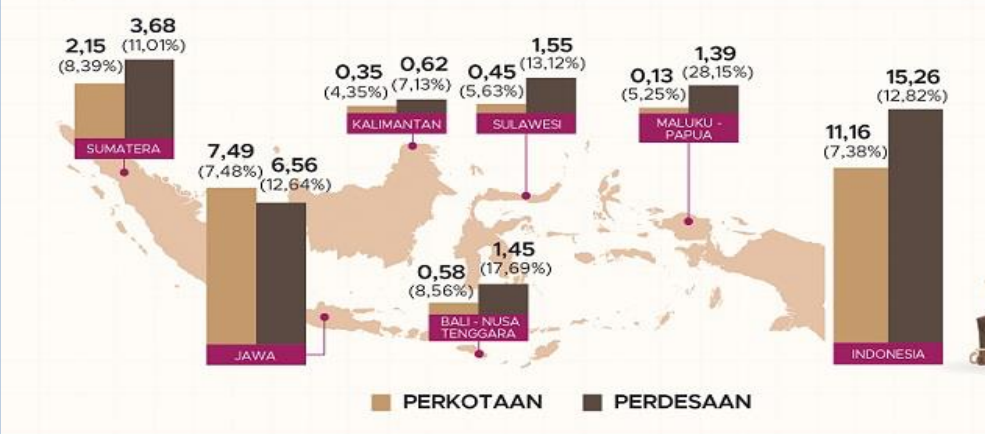

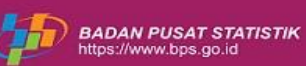

\section{CONCLUSION}

Whatever form it takes, it is packaged in beautiful and attractive packaging for the social assistance mafias related to Covid-19 which are packaged with PSBB or others carried out by the Governor/Regent/Mayor/Village Head (kuwu/lurah) and ASN, which is not in accordance with the use Integrated Social Welfare Data (DTKS) and non-DTKS data in providing Social Assistance (Bansos) to the community in an effort to overcome the impact of the corona virus pandemic (Covid-19) may be subject to Law no. 20 of 1999 as amended by Law no. 20 of 2001 concerning the Eradication of Corruption in Article 2 paragraph (2) and Article 3 Subsidiary Articles of Embezzlement 372 of the Criminal Code with a penalty of 4 (four) years in prison.

Where in Article 2 paragraphs (2) of Law no. 31 of 2001 concerning the Eradication of Corruption Crimes. It is clearly stated in the Law in the explanation section, "that a person suspected of committing a criminal act of corruption under certain circumstances will be given the death penalty". The definition of what is meant by "certain circumstances" in this provision is intended as "a burdensome for perpetrators of criminal acts of corruption if the crime is committed at a time when the country is in a state of danger in accordance with applicable laws, at the time of a national natural disaster, as a countermeasures against acts of corruption. corruption, or when the country is in a state of economic and monetary crisis". The COVID-19 event that occurred has been determined by the President through Presidential Decree (Keppres) of the Republic of Indonesia Number 12 of 2020 concerning the Determination of Non-Natural Disasters for the Spread of Corona Virus Disease 2019 (COVID-19) as National Disasters.

In addition to the threat of Law no. 20 of 1999 as amended by Law No. 20 of 2001 concerning the Eradication of Corruption, for active regional heads who are running for re-election (officials), if they violate the prohibition, they can be subject to sanctions in the form of cancellation as candidates, this is as regulated in Article 71 paragraph (3) UU no. 10 of 2016 concerning Pilkada, it is expressly stated that: "Regional heads are prohibited from using the authority, programs, and activities that are beneficial or detrimental to one pair of candidates both in their own region and in other 
regions within six months before the date of determination of the candidate pair until the determination of the candidate pair. The candidate pair was elected, why because of Law No. 23 of 2014 junto Law No. 9 of 2015 concerning Regional Government, Article 76 paragraph (1) letter (a) also states that Regional Heads and Deputy Regional Heads are prohibited from making decisions that specifically provide personal benefits, family, cronies, certain groups, or political groups that are contrary to the provisions of the laws and regulations and letter (d), abuse their authority to benefit themselves and/or harm the region they lead.

\section{REFERENCES}

- Fijnaut, C., \& Huberts, L. (2000). Corruption, integrity and law enforcement. In Corruption, integrity and law enforcement (pp. 3-34). Brill Nijhoff.

- Harahap, D. R. S. (2020). Kebijakan Formulasi Tindak Pidana Oleh Anak Yang Dapat Diupayakan Diversi Berdasarkan Aspek Keadilan Dan Tujuan Pemidanaan. Ilmu dan Budaya, 41(67).

- Junaedi, J. (2020). Efforts to Prevent Bureaucratic Corruption Based on the Piercing Principles of the Governance Veil in Realizing Good Governance and Clean Governance in Indonesia. Journal La Sociale, 1(2), 10-16. https://doi.org/10.37899/journal-la-sociale.v1i2.87

- Myrdal. G, (1977). Asian Drama, an Inquiry into the Property of Nations (Penguin Books

- Pertiwi, K., \& Ainsworth, S. (2021). "Democracy is the Cure?": Evolving Constructions of Corruption in Indonesia 1994-2014. Journal of Business Ethics, 173(3), 507-523.

- Rawls, J. (1999). A theory of justice: Revised edition. Harvard university press.

- Sari, A. D. K. (2020). "KPK Terima 118 Laporan Keluhan Penyaluran Dana Bansos, Apa Saja?" (kabar24.bisnis.com, June 8, 2020) Available from: https://kabar24.bisnis.com/read/20200608/15/1249896/kpkterima-118-laporan-keluhan-penyaluran-dana-bansos-apa-saja(Accessed June 19, 2020).

- Surachmin. C. S. (2011). Strategi dan Teknik korupsi. Jakarta: Sinar Grafika,

- Widjojanto, B. (2017). Relasi korupsi korporasi dan korupsi politik: Kajian awal melacak korupsi politik di korporasi. Integritas, 1(3): 31-52. https://doi.org/10.32697/integritas.v3i1.139.

- Widowaty, Y. (2012). Criminal Corporate Liability In Favor of The Victims In The Case Of Environmental Crime, Jurnal Yudisial, 5(2). 157-158.

CITATION: Junaedi (2022). The Death Penalty for State Officers Who Corrupted Social Aid for the Poor during COVID-19. South Asian Res J Human Soc Sci, 4(1): 34-43. 